JEREMY GELMAN

University of Michigan

GILAD WILKENFELD

E. SCOTT ADLER

University of Colorado

\title{
The Opportunistic President: How US Presidents Determine Their Legislative Programs
}

The president is the most influential policy actor in US politics, and his legislative program greatly influences Congress's agenda. Yet little research has focused on what factors affect the president's choices when constructing his agenda. We develop a theory that determines when a president will include an issue in his program. We hypothesize that presidents structure their agendas around the congressional calendar for consideration of expiring laws and salient issues. Using data over 28 years and across 12 policy areas, we find presidents build their programs around these policymaking opportunities. We assert that presidential agendas are less driven by individual priorities than previous accounts have concluded.

\section{Introduction}

In his first public comments after the 2012 election, Speaker John Boehner told reporters he expected "the president to lead" on legislative issues including the fiscal cliff, taxation, and immigration (Condon 2012). Others noted the unrealistic expectations this created since presidents have tremendous difficulty "[advancing] a coherent agenda" in divided government (Lizza 2013). While most legislative analysis focuses on what legislation the president can get passed, these discussions allude to an equally important aspect of the lawmaking processthe items that make it onto the president's policy agenda.

The president's legislative program, ${ }^{1}$ which is the set of proposals sent from the president to the legislative branch, is viewed as pivotal in presidential-congressional relations. We see evidence of the privileged place these requests have in three ways. First, they shape Congress's lawmaking agenda. Over $70 \%$ of the president's issue priorities get 
congressional consideration, and significant legislation sent by the administration is almost always debated (Edwards and Barrett 2000; Peterson 1990). Second, these policy proposals are traditionally viewed as a tool the president can use to open policy windows and create more accommodating lawmaking environments. Kingdon reports that "no other single actor in the political system has quite the capability of the president to set agendas in given policy areas..." $(1984,23)$. Third, these proposals provide cues to legislators about which issues they can successfully politicize by opposing or supporting the president's policy ideas (Lee 2009).

As the president's program heavily influences legislative attention and the level of partisanship within Congress, it is also crucial to understanding the broader policymaking process. To that end, we examine why presidents select some issues to promote in their legislative agenda and not others.

When deciding what issues to prioritize, presidents must balance their desire to get a new policy passed with the likelihood it will actually be enacted by Congress. To overcome these challenges, we argue presidents build their agendas around reliable legislative opportunities (Edwards 2009) created by Congress's internal lawmaking calendar and the level of public demand for action in a policy area. Their focus on specific legislative opportunities ensures their requests will receive consideration while providing presidents additional bargaining advantages over Congress.

To test our theory of legislative opportunities, we examine presidential policy requests in 12 prominent issue areas from 1981 through 2008. We also consider two alternative hypotheses - that fulfilling campaign promises and presidential capital dictates policy priorities. The promise-keeping hypothesis claims presidents build their programs around the pledges they made on the campaign trail. The presidentialcapital hypothesis proposes presidents expand their programs when they are more popular, win a large electoral victory, or face a favorable Congress. The findings confirm our hypotheses: expiring laws and issue salience help determine when presidents focus their attention on a policy area. Additionally, we find some evidence presidents emphasize campaign promises in their legislative agendas, but presidential capital does not significantly affect the content of the program. These results indicate why presidential programs remain generally consistent in their size and scope even as factors such as Congress's composition and presidential approval vary over time. Presidents act strategically by focusing on legislation that Congress is likely to consider anyway, establishing their position at the outset of legislative bargaining. In this sense, the president can be described as a pragmatic opportunist 
who responds to exogenous factors when deciding what policies on which to focus his attention.

\section{Common Accounts of the President's Program}

When exploring the president's agenda, political scientists have largely focused on the success presidents have in passing their priority issues through Congress. Researchers generally examine how successful presidents are at securing votes (Bond and Fleisher 1990; Edwards 1989; Fleisher, Bond, and Wood 2007) and the myriad activities they engage in while negotiating with Congress (Beckman 2010; Cameron 2000; Canes-Wrone 2006; Dickinson 2008; Kernell 2007; Neustadt 1960). While this work suggests successful executive leadership is mainly conditional on Congress's composition, scholars also find presidents can gain bargaining advantages by proposing policy ideas. Most notably, presidents can elevate an issue to the legislative agenda. Besides being uniquely situated to gain congressional attention (Kingdon 1984), Light asserts the president's program more broadly "set[s] the tone and direction of national policymaking" $(1982,1)$. Peterson (1990) finds that about $70 \%$ of presidential proposals receive congressional consideration. Early game lobbying (Beckmann 2010) and "going public" on popular issues (Canes-Wrone 2006; Kernell 2007) are two strategies that can help move final policy outcomes closer to the president's preferred position. Finally, the content of the president's program also dictates Congress's level of partisanship when it considers those issues. Presidential proposals generate more partisan outcomes than bills written within Congress and can politicize an issue even when there has been bipartisan support in the past (Lee 2009).

All of this begs the question: which issues are presidents prioritizing to begin with? Indeed, Cameron and Park note that the president's program has not been analyzed in a way that can answer the question "what do presidents choose for their legislative programs" $(2007,50)$ ? We presume presidents do not wish to waste time or capital on issues with little to no chance of clearing congressional hurdles, but we lack an adequate answer to why presidents include certain issues in their program and not others. This is due, in part, to how scholars tend to study the program. Early work on the president's agenda was limited to case studies or post hoc reflections by key personnel or former presidents that highlighted important legislative battles (Mayhew 2011; Neustadt 1955). However, these studies offer an unsystematic set of reasons an administration chose to include an issue in the president's agenda (Bond and Fleisher 1990). 
A major step in understanding the program occurred when political scientists systematically documented administration priorities based on interviews with key personnel and presidents (Light 1982; Peterson 1990). Rudalevige (2002) furthered this research by recording every unique presidential request made in a given year, but his research focused on internal administration politics rather than external lawmaking priorities. To date, few studies have explored the selection process presidents use to decide what issues end up on their agendas.

\section{Seizing Legislative Opportunities}

In determining which issues are included in the president's program, we adopt three assumptions. First, the president has an unobservable "preferred agenda" that consists of all the policies he desires Congress to enact. These latent policy preferences make the program difficult to study, as we cannot account for issues that could materialize on the agenda but never take shape (Cohen 2012). Second, we assume the president proposes policies with the goal of having them enacted. While presidents may be strategic in selecting issues, when they do focus on an issue, they do so sincerely. Third, presidents gain utility when their desired policies are passed. This can occur for many reasons, such as a boost to the president's reelection chances, improving his historical legacy or satisfying the goal of passing good public policy. Consequently, we assume policy accomplishments are a net positive for the administration (Light 1982). Accordingly, the president's utility function from his agenda being passed can be expressed as:

$$
\text { EU }\left(\text { Successful Policy }_{i}\right)=\text { Policy Utility }{ }_{i}^{*} \operatorname{Pr}\left(\text { Passage }_{i}\right) \text {, }
$$

where the expected utility from passing policy $i$ is a function of the overall utility the president would gain from bill $i$ and the probability it will pass Congress. The president's main legislative goal is to maximize his expected utility by getting as much of his program enacted as possible.

Unfortunately, this stylized equation is not directly estimable. While we have numerous variables that capture the probability a bill will pass, we cannot directly measure the policy utility the president gains from each issue on his preferred agenda. Instead, we must use observed policy proposals to distill the White House's calculus when deciding what issues to prioritize. Even so, this stylization yields a number of important insights. First, it narrows the policies we would expect the president to propose. Issues that provide little utility or have no chance of passing will be omitted from the program. Additionally, the only way 
the president can increase his expected utility for a given policy is to increase its probability of passage. Conventional wisdom suggests presidents attempt to alter this probability by utilizing various tools at their disposal (e.g., the bully pulpit or negotiating skill). In this view, the White House selects an issue to pursue and using a variety of tactics, attempts to secure the policy's passage through Congress. Cohen (2012) provides a more nuanced version of this theory, arguing presidents condition their behavior based on Congress's composition. Instead of picking any issue, administrations focus on policies they know fall outside the gridlock interval (Krehbiel 1998) in order to maximize the chance their proposal will pass. Eshbaugh-Soha (2005) similarly argues presidents choose their agendas by anticipating various political and fiscal constraints. Based on who controls Congress and the deficit's size, presidents decide how important and long lasting to make their various proposals.

Even with all these political considerations, presidential programs remain relatively large in their size and scope. From 1948 through 2008, the smallest program in a given Congress contained over 140 proposals on 20 major issue areas. Most agendas include a few hundred proposals, with the exception of Johnson's program during the Great Society that had between 600 and 700. Moreover, small programs are not the norm. Presidents only sent fewer than 200 proposals to four Congresses. This suggests presidents present Congress scores of policy ideas regardless of how difficult lawmaking conditions are at the time, which mirrors Beckmann's (2010) and Peterson's (1990) findings that presidents do not simply lay dormant when facing an opposition Congress.

This persistence in offering proposals indicates presidents systematically respond to other, nonpolitical factors when building their agendas. We argue presidential programs are relatively consistent in their size and scope because the president focuses on exogenous factors that make certain policies priorities for Congress. Leveraging knowledge about Congress's internal lawmaking calendar and the public's policymaking expectations, administrations can better forecast when a proposal has a high probability of passing.

By utilizing this approach, administrations affect the broader legislative agenda in two ways. First, they can potentially get out ahead of Congress by proposing policy on issues that will return to an unpalatable reversion point if left untended. In these situations, acting first is advantageous as the proposing actor is able to exert significant influence and move policy closer to their preferred outcome (Beckmann 2010; Krehbiel 1998). Second, presidents can place new issues on the agenda by responding to public demand for policy change. Although they 
have different effects on Congress, the underlying mechanism, that presidents strategically react to outside factors that increase a policy's probability of passage, is the same. Specifically, we argue administrations use two factors to determine when an issue moves from within to outside the gridlock interval, namely: legislative reauthorizations and policy salience.

\section{Legislative Reauthorizations}

Expiring programs create predictable legislative opportunities as reauthorizations make up a sizeable portion of the congressional agenda (Hall 2004). These policy matters serve as a baseline lawmaking activity that takes precedence over other discretionary bills (Adler and Wilkerson 2012; Kingdon 1984; Walker 1977). Building a program around Congress's preordained priorities increases the likelihood there is legislative agenda space for proposals that are part of the president's agenda. Reauthorizations provide presidents a strong bargaining position, as they can offer their own bill on such issues and engage in early-game negotiating strategies that help move policy towards their ideal points (Beckmann 2010). Additionally, building one's program around "must do" legislation is an easy way to increase the likelihood of presidential policy success and thereby to inflate a legislative "batting average" (Light 1982).

Adler and Wilkerson (2012) demonstrate that expiring legislation comes in all shapes and sizes. More likely than not, presidents are going to focus their legislative efforts on large, high-profile expiring statutesthe farm bill, the highway bill, the Higher Education Act, etc. - that are often full of dozens of statutory expirations. The development and growth of the Office of Management and Budget (OMB) facilitated presidential attention to expiring programs. For at least the past three decades, OMB specifically asks agencies to report which programs are set to expire in the upcoming year (see OMB Circular A-19). Thus, presidents have an extensive list from which they can select specific reauthorizations to include in their legislative agendas.

Additionally, other scholars have argued presidents not only track upcoming reauthorizations but explicitly wait until an expiring program requires legislative action to propose a new policy. Hall (2004) notes that President Bush waited until Head Start expired in 2003 to propose a reform package rather than include it in the No Child Left Behind Act in 2001. In the spring of 2012, President Obama gave speeches regarding student loan rates legislation on numerous college campuses just prior to its July 1, 2012 expiration (Gardner 2012). 
Focusing on expiring provisions could be interpreted as presidents not acting strategically but simply engaging in routine, administrative duties by reminding Congress to act on a certain issue. However, presidents do not include every reauthorization, big or small, on their agendas. Instead, they only elevate some expirations to their programs, which suggests doing so is a strategic action, and not an administrative obligation. ${ }^{2}$ Thus, we hypothesize:

$H 1$ : When an issue domain requires congressional reauthorization, presidents send more legislative requests on that issue.

\section{Salient Issues}

Responding to salient issues provides the president a second factor around which to build his agenda. Unlike reauthorizations, changes in immediate public concern, largely driven by exogenous events (Hill 1998), are difficult to predict. This gives the unitary president a distinct advantage over a diffuse, bicameral legislature. Congress's discretionary agenda largely is determined by pressing and highly salient events in society (Adler and Wilkerson 2012; Kingdon 1984). Once issues become highly salient, the legislature has strong incentives to act but is unlikely to have a bill to debate, much less pass. When this occurs, presidents are motivated to proffer their own bill before Congress in order to push outcomes closer to their preferred outcome (Cameron and Park 2007).

Numerous cases suggest presidents rely on issue salience when determining their legislative agendas. For instance, during President Clinton's first term, crime became a major issue of public concern. In 1993, only 9\% of Americans named crime as the country's most important problem. After firearm homicide rates peaked in 1994, 28\% rated crime as the country's most pressing problem (Cohn et al. 2013). Clinton responded by making crime a focal point of his program, and later that year Congress passed the Violent Crime Control and Law Enforcement Act. Similarly, President Bush highlighted counterterrorism policy after 9/11, and President Obama proposed financial regulations in 2009 during the Great Recession.

Conversely, it could be argued that the president causes a policy area's salience to increase by including that issue in his program. We believe this process does not explain shifts in public concern. Consistent empirical findings suggest that while presidential proposals can have a small effect in raising issue salience in the short term, their influence on the public's consciousness is fleeting (Cohen 1995, 1997). 
This is not to say presidents cannot generate public support for specific proposals. Canes-Wrone (2006) finds when presidents go public on popular issues they can increase citizens' attention towards that issue, although Edwards (2003) argues this influence is marginal. Regardless, this mechanism likely does not apply broadly to the program as presidents do not always announce their agenda publicly. Rather, many proposals are sent to Congress in messages or letters and surely vary in their level of salience. For this reason, we believe presidents' programs respond to and, in general, do not change public concern.

To examine this possible relationship, we conducted Granger causality tests between the inclusion of issues in the presidential program and issue area salience. The intuition behind this method is straightforward: When examining two variables, $\mathrm{X}$ and $\mathrm{Z}$, we are interested in determining if $\mathrm{X}$ explains $\mathrm{Z}, \mathrm{Z}$ explains $\mathrm{X}$, or if they are endogenous (they explain each other). To test these possibilities, we regress $X$ on the lagged values of $X$ and $Z$ (and do the same for $Z$ ). If $X$ is explained by $Z$ 's lagged values, but $Z$ is not predicted by X's lags, we have evidence there is a significant relationship in which $Z$ leads to a change in $X$ and not the other way around (Thurman and Fisher 1988).

Accordingly, we examined the relationship between presidential proposals and issue salience. We coded each presidential proposal from 1981 through 2008 using the Policy Agendas Project (PAP) major topic codes, ${ }^{3}$ aggregated each topic's proposals by quarter, and matched them with the corresponding "Most Important Problem" survey that measures issue salience. This created 19 panels each spanning 112 quarters. To test the relationship between these variables, we measured the effects from two Granger causality equations, formally expressed as:

$$
\text { Proposal }_{t}=\mu+\sum_{i=1}^{L} \alpha_{i} \text { Proposal }_{t-1}+\sum_{i=1}^{L} \beta_{i} \text { Salience }_{t-1}+\varepsilon_{t}
$$

and

$$
\text { Salience }_{t}=\mu+\sum_{i=1}^{L} \alpha_{i} \text { Salience }_{t-1}+\sum_{i=1}^{L} \beta_{i} \text { Proposal }_{t-1}+\varepsilon_{t}
$$

Since the dependent variable in Equation (1) is a count of presidential proposals, we estimated the first model using a fixed-effects negative binomial model. Equation (2) was estimated using a fixed-effects regression model, and we include up to three lags in each model. ${ }^{4} \mathrm{We}$ report the results of the Granger causality test in Table 1. 


\section{TABLE 1}

Presidential Proposal and Issue Salience Granger Causality Tests

(standard errors in parentheses)

\begin{tabular}{|c|c|c|c|}
\hline & Model 1 & Model 2 & Model 3 \\
\hline \multicolumn{4}{|c|}{ Part 1: Does issue salience predict presidential proposals? } \\
\hline Salience Lag 1 & $1.10(0.364)^{*}$ & $1.82(1.08)^{*}$ & $1.84(1.10)^{*}$ \\
\hline Salience Lag 2 & & $-0.704(1.10)$ & $-1.40(1.46)$ \\
\hline Salience Lag 3 & & & $0.615(1.11)$ \\
\hline \multicolumn{4}{|c|}{ Part 2: Do presidential proposals predict issue salience? } \\
\hline Proposals Lag 1 & $0.001(0.001)$ & $0.001(0.001)$ & $0.001(0.001)$ \\
\hline Proposals Lag 2 & & $-0.001(0.001)$ & $0.001(0.001)$ \\
\hline Proposals Lag 3 & & & $-0.001(0.001)$ \\
\hline
\end{tabular}

${ }^{*} p<0.05$.

The results provide support for our claim that changes in issue salience lead to presidential proposals and not vice versa. We consistently find presidents respond to increases in public concern in the previous quarter by offering more policy ideas on that same issue in the subsequent three months. On the other hand, the number of presidential proposals in previous quarters has no effect on issue salience. Thus, since presidents respond to issue salience, rather than create it, we propose:

H2: As the salience of an issue area increases, presidents send more legislative requests in that policy area.

\section{Alternatives Explanations}

Although few studies have explicitly focused on issue attention in presidents' programs, related research argues chief executives respond to a different set of factors when constructing their agendas, specifically campaign promises and presidential capital.

\section{Promise Keeping}

Presidents may build their programs around campaign promises they made during the election. Campaign issues could arise for a variety of reasons - personal priorities of the candidate, areas of emphasis to help copartisans get elected, etc.- - but regardless they will take a certain level of precedence in the program as those issues will serve as an 
explicit yardstick by which to gauge the president's success in following through on perceived mandates (Conley 2001). Previous studies indicate some campaign pledges are included on the president's agenda. Fishel (1985) finds newly elected chief executives emphasize major electoral promises in their programs but sometimes must abandon key portions of their platforms due to unfavorable governing conditions. Similarly, Shaw's (1998) analysis of Clinton's 1992 campaign pledges and subsequent performance in office suggests presidents try to fulfill their policy promises. These findings conform to similar research on congressional representation (Sulkin 2005). This suggests campaign issues are a prominent consideration when elected officials decide which issues to focus their attention and resources toward.

\section{Presidential Capital}

Scholars have consistently found that Congress passes more administration proposals as presidential "capital" increases (Barrett and Eshbaugh-Soha 2007; Rivers and Rose 1985). This concept consists of three factors: congressional composition, presidential approval, and the president's electoral mandate (Light 1982, 26). Congressional composition is considered the factor that most affects presidential agendas. Political scientists have argued presidents are more successful at getting their programs passed during unified government, when more copartisans are in Congress, and if the gridlock interval is small (Bond and Fleisher 1990; Brady and Volden 2006; Edwards 1989; Krehbiel 1998). Additionally, studies indicate presidents shape the program based on these same factors (Cameron and Park 2007; Cohen 2012).

Importantly, this work focuses on the program's relative size, not issue prioritization. Since policy windows, independent of congressional partisanship, incentivize presidents to propose bills, we should still observe numerous requests even as polarization increases. Although gridlock may censor some requests, it likely does not prevent administrations from responding to expiring bills or salient issues. Thus, while legislative composition affects the overall size of the program, its role in dictating issue attention in the agenda is likely marginal.

\section{Controls}

\section{Presidential Timing}

Scholars commonly note the president's ability to bargain with Congress is enhanced or diminished at various periods during his term in 
office. Honeymoons, "the early period of grace and good temper" (Light $1982,45)$, are commonly viewed as a moment in which presidents can win legislative victories (Beckmann and Godfrey 2007). Studies of presidential bargaining suggest most legislative requests are made early in the term, and in later years, the administration focuses on whatever did not pass during the honeymoon (Mayhew 2011; Peterson 1990). This argument follows from a mandate theory of presidential programs, in which administrations send most of their agenda immediately to Congress (Dahl 1990; Edwards 1989).

Recent work suggests presidents expand their programs during reelection years (Cohen 2012). Administrations may propose more policy ideas (1) as a signal of competence, (2) as an attempt (sometimes) to fulfill unmet campaign promises among key constituencies (Light 1982), or (3) to highlight key differences with the opposition party under divided government (Cohen 2012). Finally, presidents are less legislatively active and successful in the final year of their terms because of minimum bargaining influence with Congress (Barrett and Eshbaugh-Soha 2007) and a shift to building a historical legacy through non-legislative means (Light 1982).

\section{Issue Divisiveness}

Contentiousness associated with a given policy may affect the likelihood the White House will focus on it. Some issues generate more partisan controversy than others, which affect the probability a given policy change will be enacted (Binder 2003; Maltzman and Shipan 2008). Since presidents seek to pass as much of their programs as possible, they may avoid focusing on divisive policies and instead emphasize less contentious programs in their legislative agendas.

\section{Exogenous Conditions}

Objective conditions, such as unemployment or wars, are proposed as a factor that influences what issues presidents include in their agendas (Cohen 2012, 1995; Peterson 1990). Cohen (2012) utilizes six variables (government outlays, size of deficit, interest rates, inflation, war, and recession). These factors, as well as countless others such as violent crime rates, gas prices, consumer confidence, etc. are interrelated, and different combinations may affect policy areas in complex ways.

Without a cogent theory for including some but not others, we utilize two exogenous conditions, government outlays as a percentage of GDP and change in GDP per capita, as control variables. Government 
outlays, as a percentage of GDP, measures the relative size of government. As this variable increases, there are more policies for presidents to prioritize in their programs, which could lead to an increase in legislative requests. ${ }^{5}$ Change in GDP per capita measures the economy's relative strength. As the economy weakens, presidents will concentrate their legislative efforts in economically related issue areas or will alternatively broaden their legislative program when the economy is showing signs of strength. ${ }^{6}$

\section{Data and Measures}

\section{Dependent Variable}

To measure the president's program, we use Rudalevige's (2002) dataset constructed from the Public Papers of the President. ${ }^{7}$ Each data point is a unique legislative proposal made by the president during that year. Multiple proposals in the same year are not recorded, meaning we do not measure issues that are repeatedly emphasized by the administration. Using the Policy Agendas Project (PAP) codebook, we coded every proposal from 1981 through 2008 by major policy topic and compiled all presidential proposals in 12 main policy areas: macroeconomy, labor, defense, law and order, healthcare, social welfare, rights, trade, education, environment, international affairs, and government spending. ${ }^{8}$

We limit our analysis to these 12 areas for two reasons. First, these issues include $80 \%$ of presidents' programs and represent the most active policy domains during this time period. Although we are not certain that our results are generalizable across all issues, we have no theoretical reason to believe other policy areas would be subject to systematically different considerations. Second, we limit our analysis to issue areas in which we can accurately gauge issue salience.

Our dependent variable is a count of the number of unique legislative requests, by policy area, made in a given year. During the 28 years we examine, this amounts to 2,785 , out of 3,484 total $(80 \%)$, unique proposals. As Table 2 shows, there is large variability between policy areas as well as across time for each issue.

Additionally, the program's size fluctuates between years (from a minimum of 50 in 1985 to a maximum of 225 in 1999), but importantly no single issue dominates any president's agenda in a given year. ${ }^{10}$ To provide a sense of how many proposals by policy area are included in the program on an annual basis, Table 3 lists the average number of proposals, by issue, sent by the president to Congress in a year. 
TABLE 2

Number of Policy Proposals Across Presidencies

\begin{tabular}{lrrrr}
\hline & Reagan & GHW Bush & Clinton & GW Bush \\
\hline Macroeconomy & 39 & 16 & 47 & 41 \\
Rights & 48 & 5 & 25 & 17 \\
Healthcare & 43 & 12 & 148 & 79 \\
Labor & 27 & 13 & 125 & 50 \\
Education & 32 & 25 & 121 & 42 \\
Environment & 19 & 35 & 31 & 32 \\
Law and Order & 41 & 66 & 166 & 49 \\
Social Welfare & 21 & 14 & 57 & 33 \\
Defense & 58 & 20 & 66 & 98 \\
Trade & 65 & 9 & 66 & 41 \\
Foreign Policy & 114 & 82 & 232 & 162 \\
Government Spending & 72 & 48 & 99 & 34 \\
& & & & \\
Total & 579 & 345 & 1183 & 678 \\
Overall Total & 809 & 423 & 1373 & 876 \\
\hline
\end{tabular}

TABLE 3

Average Annual Number of Presidential Proposals by Issue Area, 1981-2008

\begin{tabular}{lc} 
Issue Area & Average Number \\
\hline Macroeconomy & 5.07 \\
Rights & 3.36 \\
Healthcare & 10.14 \\
Labor & 7.68 \\
Education & 7.86 \\
Environment & 3.79 \\
Law and Order & 11.36 \\
Social Welfare & 4.46 \\
Defense & 7.43 \\
Trade & 2.64 \\
Foreign Policy & 8.07 \\
Government Spending & 8.93
\end{tabular}

Notably, while each administration's legislative agenda contains a few hundred proposals annually, the program is relatively diffuse when disaggregated by policy area. Thus, slightly more or fewer policy ideas about an issue can constitute a large change in the program's focus. 


\section{Independent Variables}

To determine whether reliable legislative opportunities influence presidential program development, we used the following measures. First, we measured Expirations by counting the number of authorized programs set to expire in laws that were discussed in the main chapters of the annual Congressional Quarterly Almanac each legislative session. Each identified statute was initially coded by PAP topic area, and every subsequent expiring provision therein was also coded into the same topic area. Since our focus is on expiring authorizations, we limited our attention to authorizing legislation and excluded appropriations bills, which rarely include novel expiration language that is not also referenced in a concomitant authorization bill (Adler and Wilkerson 2012). ${ }^{11}$

Second, to summarize Issue Salience, we followed standard practice by using Gallup's Most Important Problem polling data to capture issues of public concern (Canes-Wrone 2006; Cohen 1995). Using the PAP method for aggregating these open-ended poll questions, we coded and then averaged the percentage of the public who listed a policy area as the most important problem in a given year. Our empirical analysis tests whether issue salience affects the number of presidential proposals offered in the same year.

To assess the promise-keeping hypothesis, we measure Campaign Promises by calculating the number of words the president devoted to a given policy area compared to all policy discussion in his nominating convention speech. ${ }^{12}$ This ratio assesses how much emphasis he deliberately assigned to an issue in a situation with significant time constraints. To test the presidential timing and capital-alternative hypothesis, we included dummy variables for presidential Honeymoons (the first year of the first term), Reelection Year (the last year in a first term), and Lame Ducks (any legislative session occurring after the November elections). We used Gallup polls, averaged by year, to measure Presidential Approval. Additionally, we measured a president's Electoral Margin by calculating the difference between the number of electoral votes the winning candidate received from that which the other major party candidate received. ${ }^{13}$ Finally, we measured Congressional Composition three different ways: (1) a dummy variable for years of divided government, (2) the proportion of presidential copartisans in Congress that year, and (3) using Chiou and Rothenberg's (2003) methodology, we computed four variations of the gridlock interval.

Finally, following from previous research that variously found policy-specific conflict can heighten the likelihood of legislative activity (Adler and Wilkerson 2012; Maltzman and Shipan 2008), reduce it 
(MacDonald 2007), or have mixed effects (Binder 2003), we control for Issue Divisiveness. Specifically, we calculated the percentage of party-unity votes in the House and the Senate for each policy area in the previous year. Since either chamber can act as a choke point to lawmaking, we included the value for whichever chamber had a higher percentage of party-unity votes.

\section{Analysis}

Since our data are time-series cross-sectional counts of presidential legislative requests, we estimated our results using a panel negative binomial model with fixed effects. ${ }^{14}$ With 12 different policy areas measured across 28 years, our $\mathrm{N}=336$. To test our hypotheses, we specify a baseline model that includes expirations, salience, government outlays, change in GDP, and the presidential timing variables. ${ }^{15}$ Our legislative opportunity theory garners initial support in the baseline model shown in Table 4.

As predicted, expirations and salience are both positive and significant. Additionally, the coefficient magnitudes reflect our expectations concerning how many proposals each item generates. The results of the legislative opportunity variables are consistent across all model specifications that follow, which lend strong support to their robustness as factors explaining what policy issues the president will pursue in Congress. ${ }^{16}$

Since large expiring laws tend to include hundreds of individual sunsets, we argued presidents prioritize statutes with sizable numbers of expirations and largely ignore laws with small numbers of expiring provisions. An increase of 12 expiring provisions (a one standard deviation change) leads the president to increase the number of policy proposals in that policy area by $8 \%$. As Figure 1 illustrates, the president will increase the number of policy proposals he issues in a given policy area by $78 \%$ (an increase of more than two unique policy proposals) when that policy area has 91 expiring provisions, the maximum observed value in these data. While the actual effect sizes are relatively small, the nature of the effect is significant considering our count is of unique proposals and not repeated advocacy of any given proposal in the program. This finding reflects our expectations and conforms to similar results elsewhere (Adler and Wilkerson 2012). When the president sees government funding at stake in bills that have a high probability of passage, he consistently increases his effort to influence the process and legislative outcomes. 
378 Jeremy Gelman, Gilad Wilkenfeld, and E. Scott Adler

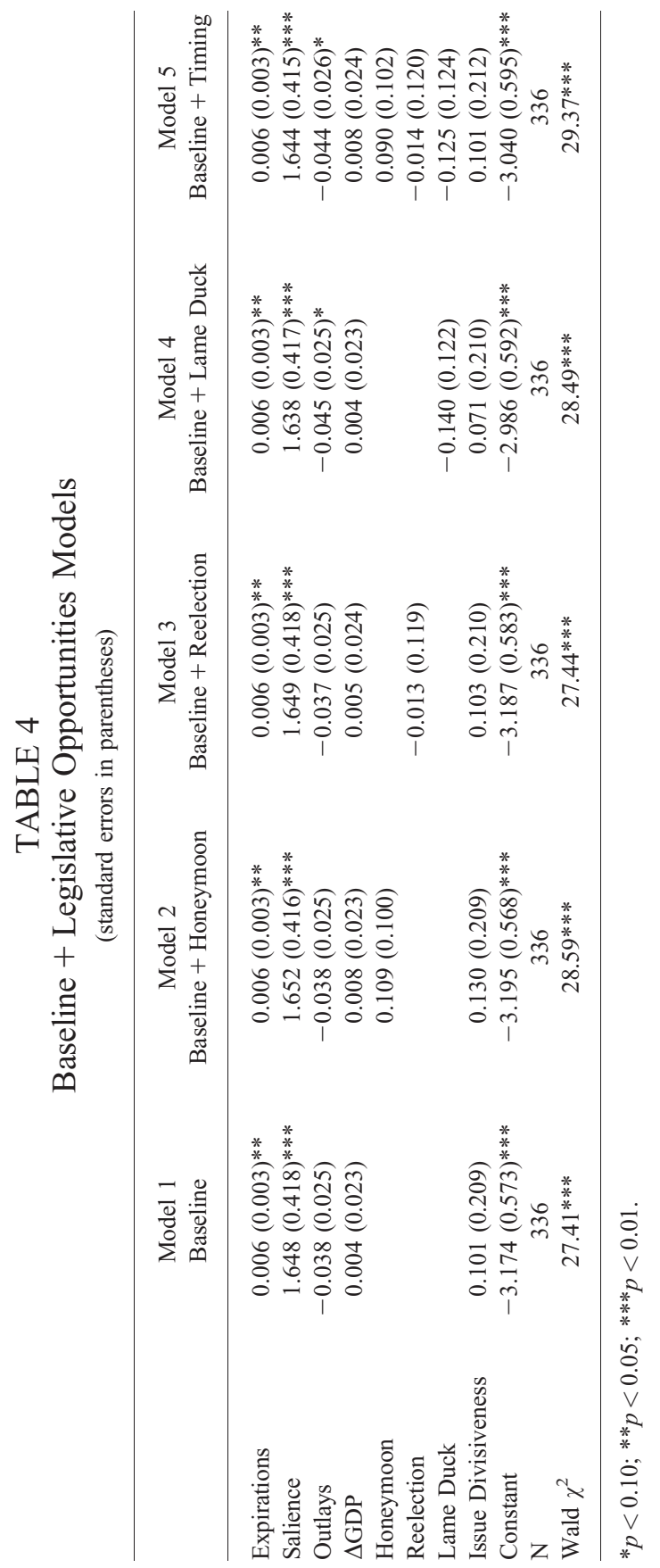


FIGURE 1

Expiring Provisions and the Presidential Program

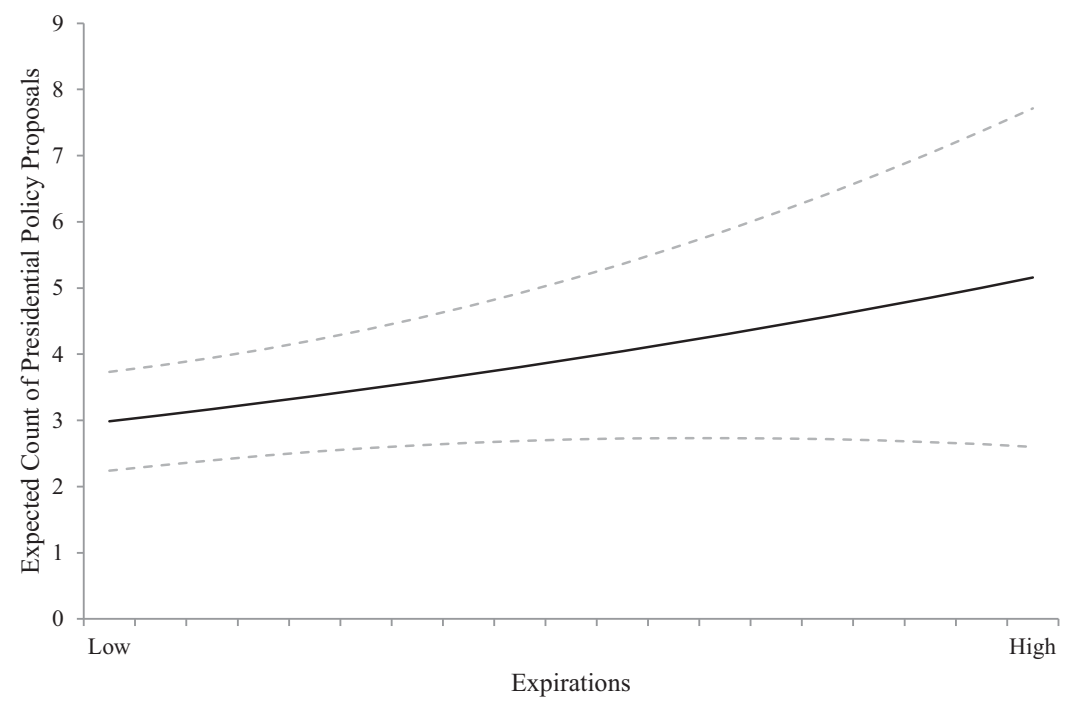

The impact of issue salience on policy emphasis is much larger by comparison. The magnitude of issue salience reflects presidential motivation to propose bills as citizen concern increases. Our results are in line with Cameron and Park's (2007) burden-sharing model and reflect a consistent finding in the American politics literature that suggests a type of responsiveness to public opinion (see Burstein 2014 for a review; Page and Shapiro 1983). Citizen concern places pressure on both the White House and Congress simultaneously, thus increasing the probability of action. While expirations represent punctuating events within government, public pressure is likely a forceful influence on the president with immediate consequences for electoral gains or political capital. This relationship is evident in Figure 2, which shows increases in issue salience can lead to presidents, on average, nearly tripling the number of proposals they send to Congress in that policy area. In addition, traditional factors thought to influence presidential behavior, such as the timing factors included in these models, do not diminish the influences we discuss throughout this article.

\section{Promise Keeping}

In addition to the factors identified as having an effect on the probable success of a bill - the number of provisions set to expire and 


\section{FIGURE 2}

Issue Salience and the Presidential Program

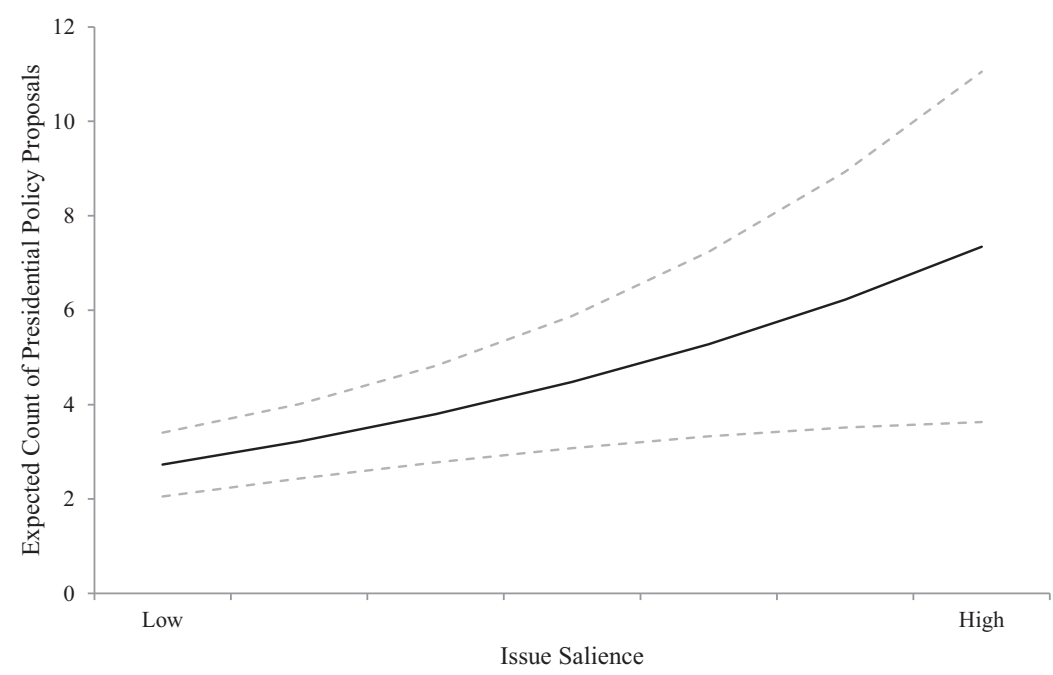

the relative public salience of the issue - campaign promises may significantly influence what issues presidents tend to emphasize in their programs. Table 5 shows that, in addition to our legislative opportunities variables, issues the president emphasizes on the campaign trail also significantly increase the number of policy proposals the president transmits to Congress.

As shown in Figure 3, the president increases the number of policy proposals he transmits to Congress by about $48 \%$ when he also emphasized the same policy issue at the highest observed level during the campaign. However, it is important to note that this finding is not robust when including issue divisiveness and in models controlling for other important dimensions of presidential influence. None of the other factors included in the baseline model in Table 4-budget outlays, change in GDP, and issue divisiveness - move the president to act in a significant manner when controlling for campaign issue emphasis.. Both legislative opportunities variables are still positive and significant. While the effect of expiring provisions on the number of policy proposals the president transmits to Congress is identical to the effect in the baseline model, the effect of salience is slightly smaller. In this model that includes both legislative opportunity and promise-keeping variables, issue salience leads the president to nearly double the number of policy proposals transmitted to Congress. 
TABLE 5

Promise Keeping + Legislative Opportunities Model

(standard errors in parentheses)

\begin{tabular}{lc}
\hline Variable & Coefficient \\
\hline Expirations & $0.006(0.003)^{* *}$ \\
Salience & $1.196(0.480)^{* *}$ \\
Outlays & $-0.045(0.026)^{*}$ \\
$\Delta$ GDP & $0.005(0.024)$ \\
Honeymoon & $0.100(0.101)$ \\
Reelection & $-0.004(0.120)$ \\
Lame Duck & $-0.132(0.123)$ \\
Campaign Issue Emphasis & $1.542(0.829)^{*}$ \\
Issue Divisiveness & $0.076(0.212)$ \\
Constant & $-2.993(0.597)^{* * *}$ \\
$N$ & 336 \\
Wald $\chi^{2}$ & $34.15^{* * *}$ \\
\hline
\end{tabular}

${ }^{*} p<0.10 ;{ }^{* *} p<0.05 ; * * * p<0.01$.

FIGURE 3

Campaign Issue Emphasis and the Presidential Program

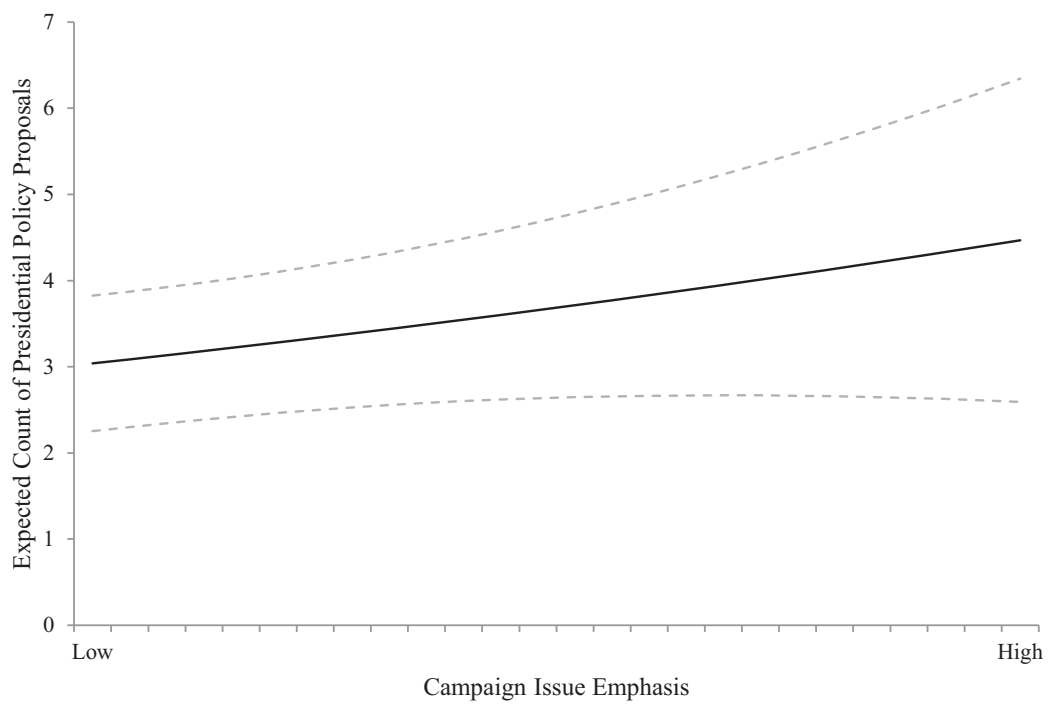




\section{Presidential Capital}

We put the legislative opportunity theory to a more rigorous test by estimating additional models including factors related to presidential capital. Table 6 reports several analyses that include our baseline model with variables that capture presidential capital theory and a final model that includes the five main capital variables: presidential approval, the president's electoral margin of victory, divided government, congressional composition, and gridlock. If presidential capital, not other legislative opportunities, predicts presidential issue prioritization, these new variables should be significant while expirations and salience will lose their explanatory power. However, as the results in Table 6 show, this is not the case.

Again, the results support the legislative opportunity theory. Expirations and salience are positive and significant in every specification. Much like the promise-keeping models, the magnitude of the effect of these two variables is nearly identical to the baseline-only model. In contrast, presidential approval and electoral margin have no consistent substantive effect. Notably, each measure of legislative composition yields a null result. ${ }^{17}$ Two main inferences derive from these findings. First, the factors that predict presidential success on roll-call votes do not explain issue prioritization in the program. Second, hostile Congresses do not simply constrain the policies on which the presidents ask Congress to act. Instead, these agendas and their eventual success suggest a complex relationship between proposing and bargaining as different lawmaking opportunities may offer better prospects for certain requests than others.

In many ways, the strength of our approach is the robustness of the findings and the ability of these explanations to hold up in the face of the canonical explanations of presidential influence. In Table 7, we combine factors related to promise keeping, presidential capital, and timing along with the opportunity theory variables. The analysis demonstrates that factors related to strategic opportunities consistently continue to explain variation in the number of policy proposals a president makes. Issue salience and the presence of expiring provisions both predict an increase in presidential policy proposals in that issue area. No other variables in the model, related to campaign promises, timing, or capital significantly predict presidential issuance of policy proposals to Congress.

\section{Discussion and Conclusion}

The policy program is commonly viewed as a tool of presidential administrations to gain attention from Congress and open new policy 


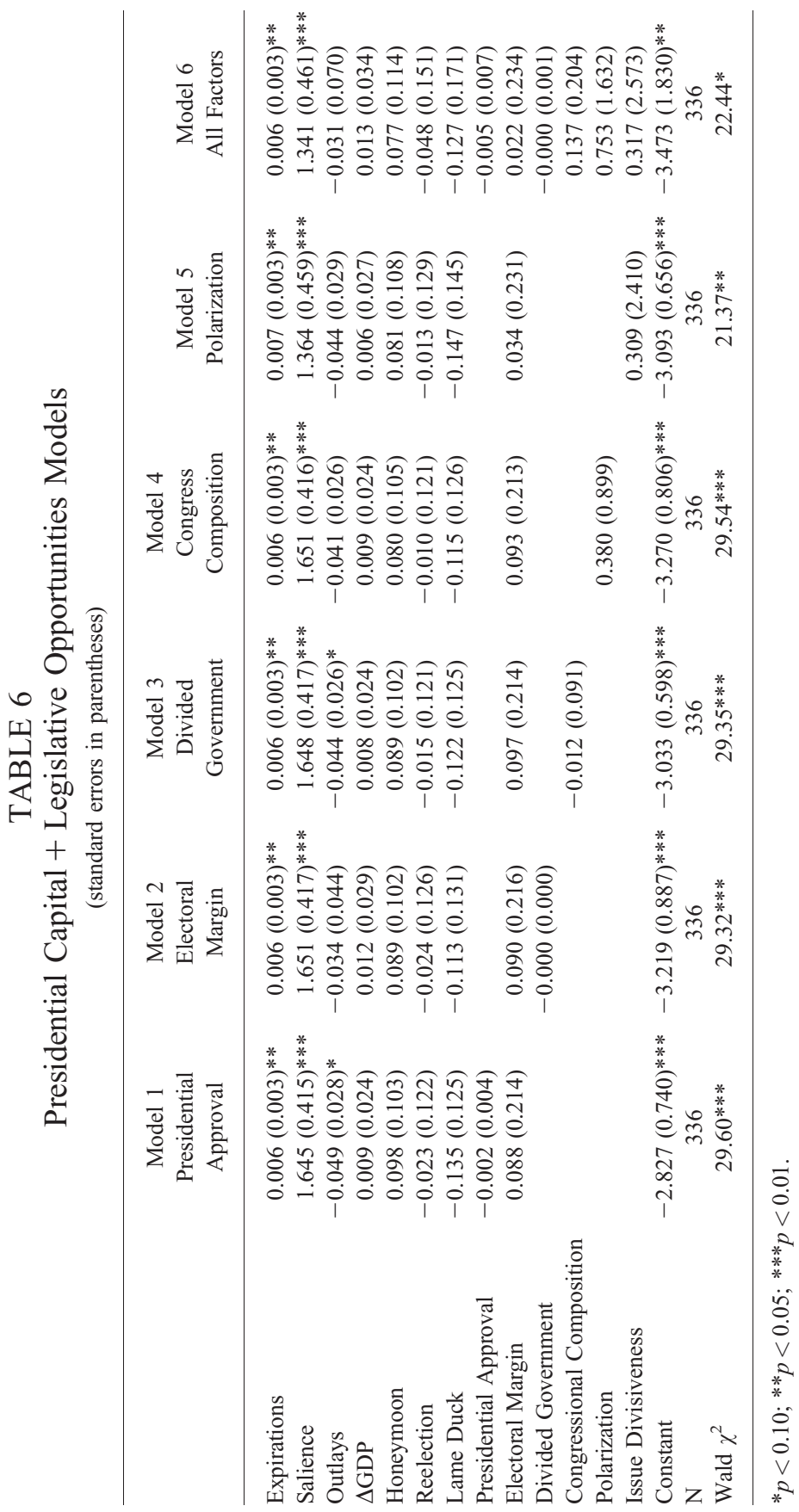


TABLE 7

Legislative Opportunities + All Alternative Hypotheses and Controls Model

(standard errors in parentheses)

\begin{tabular}{lc}
\hline Variable & Coefficient \\
\hline Expirations & $0.006(0.003)^{*}$ \\
Salience & $1.192(0.522)^{* *}$ \\
Outlays & $-0.029(0.070)$ \\
$\Delta$ GDP & $0.013(0.034)$ \\
Honeymoon & $0.075(0.114)$ \\
Reelection & $-0.045(0.151)$ \\
Lame Duck & $-0.125(0.171)$ \\
Campaign Issue Emphasis & $0.613(1.009)$ \\
Presidential Approval & $-0.005(0.007)$ \\
Electoral Margin & $-0.000(0.001)$ \\
Divided Government & $0.126(0.205)$ \\
Congressional Composition & $0.755(1.631)$ \\
Gridlock & $0.076(2.605)$ \\
Issue Divisiveness & $0.013(0.234)$ \\
Constant & $-3.508(1.835)^{*}$ \\
$\mathrm{~N}$ & 336 \\
Wald $\chi^{2}$ & $22.97^{*}$ \\
\hline
\end{tabular}

${ }^{*} p<0.10 ;{ }^{* *} p<0.05 ;{ }^{* *} p<0.01$.

windows. While recent studies of the program have emphasized the role partisan alignment between the branches plays in decreasing the agenda's size (particularly divided government), basic questions about issue priorities have been overlooked. We considered why some issues, and not others, are included in the president's program. This approach has allowed us to highlight patterns in presidential administrations rather than idiosyncrasies of the individual president. Our findings, that presidents respond to reliable legislative opportunities to maximize their proposals' chances of being enacted, help explain the seemingly disjointed agendas the White House sometimes adopts. In addition, we find evidence that presidents are mindful of promises made on the campaign trail and emphasize these issues in their legislative agendas. Common complaints that presidents do not focus on ideological agendas can be understood as a strategic choice. Presidents are constrained by a set of independent factors that influence when policy makers in Washington will focus on a particular issue.

From an agenda-setting perspective, these findings suggest the concept of presidential influence needs additional refining. Conceived 
principally as a method through which administrations open lawmaking windows for their policies, our results indicate the presidential program is also built in response to other exogenous factors. Many times, presidents choose to focus on policies that will soon be debated in Congress or are salient to the public. In doing so, presidents can leverage them in an attempt to increase the likelihood their proposal is enacted. Additionally, presidential attention to factors like policy expirations and salience offers important texture to the role of legislative composition in explaining lawmaking. In this view, presidents are constrained from proposing new policies by the array of preferences present in Congress. While true, the more interesting result is that presidents attempt to leverage reversion points created by expirations and public demand for policy to enact important items on their agenda.

Based on these results, three future avenues of research can expand our understanding of the president's program. First, our data catalogue the composition of the president's program but not the dynamics of presidential emphasis on certain issues in bargaining with Congress. Though encouraged by the robustness of our findings when compared to prevailing theories of presidential influence in the legislative arena, we believe the magnitude of the effects observed are artificially low because presidential emphasis is not considered.

Second, we treat proposals as independent from one another. However, emphasizing one issue may have a crowding out effect on others - meaning issue areas compete for presidential attention. Policy competition remains an elusive but important topic that warrants more attention. Finally, our analysis does not consider whether individual policy requests are relatively extreme or moderate. Cohen (2012) finds presidents send centrist proposals during divided government, but this may be conditional on which factor has created the policy window. Examining whether issue salience generates more ideological proposals than expirations could explain why presidents sometimes take a hardline approach with Congress.

Our study provides a new perspective on presidential legislative activism. It offers evidence that presidents act strategically when proposing their agenda, but in a way different than has been previously noted. By adhering to independently created legislative opportunities, administrations choose to constrain themselves in order to maximize their agenda's impact. The result is a more nuanced understanding of the president's role in the lawmaking process. Rather than being endowed with a privileged, first-mover position, presidents cultivate that role by molding their program around specific issues. In short, the president is not dominant in the agenda-setting process, but strategic. 
Jeremy Gelman <jgelman@umich.edu > is a Ph.D. candidate in the Department of Political Science at the University of Michigan, 5700 Haven Hall, 505 South State St., Ann Arbor, MI 48109. Gilad Wilkenfeld $<$ gilad.wilkenfeld@colorado.edu $>$ is a Ph.D. candidate in the Department of Political Science at the University of Colorado, Campus Box 333, Boulder, CO 80309-0333. E. Scott Adler<esadler@colorado. edu $>$ is Professor of Political Science at the University of Colorado, Campus Box 333, Boulder, CO 80309-0333.

\section{NOTES}

For helpful comments we thank Brian Hallett, Molly Reynolds, Chuck Shipan, seminar participants at the University of Michigan and the University of Colorado Boulder, and three anonymous referees. Additional thanks to Heather Larsen-Price and Andy Rudalevige for generously sharing their data and providing useful guidance. We are responsible for all remaining errors.

1. In this article, we use the terms "president's agenda" and "president's program" interchangeably.

2. This assertion was confirmed in a private conversation one of the authors had with Matt Vaeth, a Director of the Legislative Reference Division of OMB during the Obama presidency. Vaeth stated that the president frequently chooses agenda items from the list of large reauthorizations up for consideration in the coming year.

3. These presidential proposal data were collected using Rudalevige's (2002) method, which is further explained in the data section of this article.

4. This is for two reasons. First, changes in the number of presidential proposals or the level of issue salience seem unlikely to occur nine months after a given event occurs. Second, presidential proposals mentioned one year apart are spuriously correlated based on seasonal factors. For instance, more proposals are sent in January and February because of the State of the Union and budget message while fewer are observed in the summer when Congress is not in session.

5. Unfortunately, the OMB coding scheme used to classify each program's outlays cannot be mapped onto the Policy Agendas Project coding in a meaningful way.

6. We tested for potential variation in program due to presidential specific effects by including president-centered dummies in each model. The president-centered variables were never significant, nor did they impact the models, so they were not included in the final analyses.

7. Rudalevige's data end at 1996. The data for 1997-2008 were collected replicating and extending the methodology outlined by Rudalevige (2002, 67-72). These data reflect specific legislative requests included in the Public Papers of the President, not full draft bills, which have been used in other studies (Light 1982).

8. Our analysis is at the major topic level because none of the other variables can be parsed from the major topic to the subtopic level. Many reauthorizations cover multiple subtopics, and most issue salience polls identify major topic issues. Additionally, other work on presidential issue attention uses major topic codes (e.g., Larsen-Price 2012). 
9. We do not include treaties and international agreements.

10. No issue area makes up more than $21 \%$ of the program in a single year.

11. The number of expirations in our data set ranges from 0 to 72 in a policy area for a given year.

12. Convention acceptance speeches are commonly used to measure presidential and partisan priorities (see Gerring 1998; Petrocik, Benoit, and Hansen 2003). To develop this measure, we counted words in the convention speech at the first mention of any policy issue. This excluded the various "thank you's" and stories at the beginning and end of each speech. The denominator for this ratio is the total number of policy words in the speech. Using the PAP codebook, we coded the number of words the president devoted to a policy area. We excluded instances in which an incumbent president mentioned what he did in his previous term or a candidate attacked their opponent without offering their alternative plan. Thus, the sum of coded policy words does not equal the total number of policy words in the convention speech.

13. We did test other potential measures to capture the size of the electoral margin, including difference in percent popular vote received by the two major-party candidates, overall electoral votes received, and percent popular vote received by the winner. All these measures highly correlate and do not change our models' results.

14. We tested each variable to ensure it was stationary. Only GDP required differencing, creating our $\Delta \mathrm{GDP}$ control variable. The results of Hausman specification test for the appropriateness of fixed effects were all significant indicating a need to use fixed effects for policy area.

15 . We estimated the model using a variety of different control variables including war, unemployment, and size of the deficit. None substantively changed the findings.

16. As a robustness check, we also estimated the baseline model when ordering the data by major policy area and congressional term (instead of year). The findings of the baseline model when ordering the data by congressional term are nearly identical to those obtained when ordered by year. We employ year as our time unit because reducing the time dimension to congressional terms dramatically decreases the number of observations and induces a serious concern about biased estimates. Moreover, there is ample scholarly evidence supporting the use of year when evaluating legislative agendas as they can fluctuate within a congressional session (e.g., Adler and Wilkerson 2012; Maltzman and Shipan 2008).

17. We tested different variations of the gridlock interval in the single-variable model and each measure of legislative composition in the model. None of these combinations changed the substantive results as the covariates associated with our theory were consistently significant.

\section{REFERENCES}

Adler, E. Scott, and John Wilkerson. 2012. Congress and the Politics of Problem Solving. New York: Cambridge University Press.

Barrett, Andrew W., and Matthew Eshbaugh-Soha. 2007. "Presidential Success on the Substance of Legislation." Political Research Quarterly 60(1): 100-12.

Beckmann, Matthew N. 2010. Pushing the Agenda: Presidential Leadership in U.S. Lawmaking, 1953-2004. New York: Cambridge University Press. 
Beckmann, Matthew N., and Joseph Godfrey. 2007. "The Policy Opportunities in Presidential Honeymoons." Political Research Quarterly 60(2): 250-62.

Binder, Sarah. 2003. Stalemate: Causes and Consequences of Legislative Gridlock. Washington, DC: Brookings Institution Press.

Bond, Jon R., and Richard Fleisher. 1990. The President in the Legislative Arena. Chicago: University of Chicago Press.

Brady, David W., and Craig Volden. 2006. Revolving Gridlock: Politics and Policy from Jimmy Carter to George W. Bush. Boulder, CO: Westview.

Burstein, Paul. 2014. American Public Opinion, Advocacy, and Policy in Congress. New York: Cambridge University Press.

Cameron, Charles. 2000. Veto Bargaining: Presidents and the Politics of Negative Power. New York: Cambridge University Press.

Cameron, Charles, and Jee-Kwang Park. 2007. "A Primer of the President's Program." In Presidential Leadership: The Vortex of Power, ed. Bert Rockman and Richard Waterman. New York: Oxford University Press, 46-79.

Canes-Wrone, Brandice. 2006. Who Leads Whom? Presidents, Policy, and the Public. Chicago: University of Chicago Press.

Chiou, Fang-Yi, and Rothenberg, Lawrence. 2003. "When Pivotal Politics Meets Partisan Politics." American Journal of Political Science 47(3): 503-22.

Cohen, Jeffrey. 1995. "Presidential Rhetoric and the Public Agenda." American Journal of Political Science 39(1): 87-107.

Cohen, Jeffrey. 1997. Presidential Responsiveness and Public Policy-Making: The Public and the Policies That Presidents Choose. Ann Arbor: University of Michigan Press.

Cohen, Jeffrey. 2012. The President's Legislative Policy Agenda, 1789-2002. New York: Cambridge University Press.

Cohn, D’Vera, Paul Taylor, Mark Hugo Lopez, Catherine A. Gallagher, Kim Parker, and Kevin T. Maass. 2013. "Gun Homicide Rate Down 49\% since 1993 Peak; Public Unaware." Pew Social \& Demographic Trends. http://www.pewsocialtrends.org/2013/05/07/gun-homicide-rate-down-49-since-1993-peak-publicunaware/(accessed August 3, 2013).

Condon, Stephanie. 2012. "Boehner: Obama 'has to lead' on taxes, immigration." CBS News. http:/www.cbsnews.com/8301-250_162-57547732/boehner-obama-hasto-lead-on-taxes-immigration/ (accessed March 6, 2013).

Conley, Patricia. 2001. Presidential Mandates: How Elections Shape the National Agenda. Chicago: University of Chicago Press.

Dahl, Robert. 1990. "Myth of the Presidential Mandate." Political Science Quarterly 105(3): 355-72.

Dickinson, Matthew. 2008. "The Politics of Persuasion: A Bargaining Model of Presidential Power." In Presidential Leadership: The Vortex of Power, ed. Bert Rockman and Richard Waterman. New York: Oxford University Press, 277310.

Edwards, George. 1989. At the Margins: Presidential Leadership of Congress. New Haven, CT: Yale University Press.

Edwards, George. 2003. On Deaf Ears: The Limits of the Bully Pulpit. New Haven, CT: Yale University Press. 
Edwards, George. 2009. The Strategic President: Persuasion and Opportunity in Presidential Leadership. Princeton, NJ: Princeton University Press.

Edwards, George, and Andrew Barrett. 2000. "Presidential Agenda Setting in Congress." In Polarized Politics: Congress and the President in a Partisan Era, ed. Jon Bond and Richard Fleisher. Washington, DC: CQ Press, 109-33.

Eshbaugh-Soha, Matthew. 2005. "The Politics of Presidential Agendas." Political Research Quarterly 58(2): 275-68.

Fishel, Jeff. 1985. Presidents \& Promises. Washington, DC: CQ Press.

Fleisher, Richard, Jon R. Bond, and B. Dan Wood. 2007. "Which Presidents Are Uncommonly Successful in Congress?" In Presidential Leadership: The Vortex of Power, ed. Bert Rockman and Richard Waterman. New York: Oxford University Press, 191-214.

Gardner, Amy. 2012. "Obama Takes His Student Loan Pitch to Campuses in North Carolina, Colorado." Washington Post. http://articles.washingtonpost.com/ 2012-04-24/politics/35450739_1_young-voters-student-loans-president-obama (accessed October 31, 2013).

Gerring, John. 1998. Party Ideologies in America 1828-1996. New York: Cambridge University Press.

Hall, Thad E. 2004. Authorizing Policy. Columbus: Ohio State University Press.

Hill, Kim Quaile. 1998. "The Policy Agendas of the President and the Mass Public: A Research Validation and Extension." American Journal of Political Science 42(4): 1328-34.

Kernell, Samuel. 2007. Going Public: New Strategies of Presidential Leadership. Washington, DC: CQ Press.

Kingdon, John W. 1984. Agendas, Alternatives, and Public Policies. New York: Longman.

Krehbiel, Keith. 1998. Pivotal Politics: A Theory of U.S. Lawmaking. Chicago: University of Chicago Press.

Larsen-Price, Heather. 2012. "The Right Tool for the Job: The Canalization of Presidential Policy Attention by Policy Instrument.” Policy Studies Journal 40(1): 147-68.

Lee, Frances E. 2009. Beyond Ideology: Politics, Principles, and Partisanship in the U. S. Senate. Chicago: University of Chicago Press.

Light, Paul. 1982. The President's Agenda: Domestic Policy Choice from Kennedy to Clinton. Baltimore, MD: Johns Hopkins University Press.

Lizza, Ryan. 2013. "The Powerless Presidency." The New Yorker Blogs. http://www. newyorker.com/news/daily-comment/the-powerless-presidency (accessed March 6, 2013).

MacDonald, Jason. 2007. "Legislative Productivity and Policy Conflict: Reauthorizing Laws in the U.S. Congress, 1987-2007." Unpublished manuscript, West Virginia University.

Maltzman, Forrest, and Charles Shipan. 2008. "Change, Continuity, and Evolution of the Law." American Journal of Political Science 52(2): 252-67.

Mayhew, David R. 2011. Partisan Balance: Why Political Parties Don't Kill the U.S. Constitutional System. Princeton, NJ: Princeton University Press.

Neustadt, Richard E. 1955. "Presidency and Legislation: Planning the President's Program.” American Political Science Review 49(4): 980-1021. 
Neustadt, Richard E. 1960. Presidential Power and the Modern Presidents: The Politics of Leadership from Roosevelt to Reagan. New York: Simon and Schuster.

Page, Benjamin I., and Robert Y. Shapiro. 1983. "Effects of Public Opinion on Policy." American Political Science Review 77(1): 175-90.

Peterson, Mark A. 1990. Legislating Together: The White House and Capitol Hill from Eisenhower to Reagan. Cambridge, MA: Harvard University Press.

Petrocik, John, William Benoit, and Glenn Hansen. 2003. "Issue Ownership and Presidential Campaigning: 1952-2000.” Political Science Quarterly 118(4): 599-626.

Rivers, Douglas, and Nancy L. Rose. 1985. "Passing the President's Program: Public Opinion and Presidential Influence in Congress." American Journal of Political Science 29(2): 183-96.

Rudalevige, Andrew. 2002. Managing the President's Program: Presidential Leadership and Legislative Policy Formulation. Princeton, NJ: Princeton University Press.

Shaw, Carolyn. 1998. "President Clinton's First Term: Matching Campaign Promises with Presidential Performance." Congress and the Presidency 25(1): 43-65.

Sulkin, Tracy. 2005. Issue Politics in Congress. New York: Cambridge University Press.

Thurman, Walter, and Mark Fisher. 1988. "Chickens, Eggs, and Causality, or Which Came First?” American Journal of Agricultural Economics 70(2): 237-38.

Walker, Jack. 1977. "Setting the Agenda in the U.S. Senate: A Theory of Problem Selection." British Journal of Political Science 7(4): 423-45. 